Jurnal Edukasi, Volume 5 No.2, Oktober 2019

EISSN. 2598-4187 ISSN. 2443-0455

\title{
STUDENT'S PERSPECTIVES TOWARD A-AIKEM 3 MODEL IN GROUP WORK PRESENTATION
}

\author{
Henry Rio Putranto \\ Widya Mandala Catholic University Surabaya
}

\begin{abstract}
As there is a tendency to regard that a classroom without the label of cooperative learning is not a good one, recent instructional practices then often utilize group work to encourage students to gain knowledge from one another - to assist and to seek assistance from their peers in addition to from the classroom teacher. Classrooms have the typical characteristics of small groups. With the trend to incorporate cooperative learning in the classroom practices, this Positive Interdependence is undoubtedly to be imposed to obtain the beneficial outcomes of cooperative efforts. This research would like to employ a new model in group work presentation called A-aikem 3. This A-aikem 3 model is an innovative group work presentation model which emphasizes on CL approach. This model can be used to strengthen positive interdependence, individual accountability, interpersonal and also group processing skill from students. Basically,A-aikem 3 model is one of many A-aikem models formulated and designed by Tamah and Prijambodo on their book. The A-aikem 3 model developed based on three new insights that are (1) transition from individual (conventional) assessments to group assessment, (2) transition from individual assessment to peer assessment, and (3) transition from Individual assessment without discussion to a representative assessment with discussion. (Tamah \& Prijambodo, 2015 in Tamah, 2017) Deriving from the title of this thesis and the background of the study, two relevant research questions are formulated as follows: How do the undergraduate students perceive A-aikem 3 model? What are the positive and negative feedbacks of A-aikem 3 model'? In relation to the research questions above, this study aims to investigate the student's perspective towards A-aikem 3 model and also their feedback after experiencing Aaikem 3 model.
\end{abstract}

Key words: cooperative learning, positive interdependence, perceptions

\section{Introduction}

There is an ever increasing need

for interdependence in our educational environment today. Providing students

with the tools to effectively work in a collaborative and cooperative 
environment should be our priority as teachers. Cooperative learning $(\mathrm{CL})$ is one way to provide students with a well defined framework from which they can learn from one another. According to Slavin (1996 in Strahm, 2007, p.65) CL has been hailed as 'one of the greatest success stories in the history of educational innovation'.

In spite of research evidence supporting group work, many teachers still have worries with group work implementation. To this particular concern, Brown (2001) strengthens the need of careful planning and management. What matters is the lack of additional effort or essential conditions which might be related to the characteristics that make cooperative learning different from common group work.

Derived from the concerns above, this study tries to focus on one of the instructional practices in CL, which is group presentation. According a recent research conducted by Tamah (2015), teachers often employ group work presentation to assess the outcome of CL through group work activities. She states that there are some concerns when conventional group presentation was carried out by each group member. On her article, Tamah (2015) highlights the diminution of the two most important elements of group work namely positive interdependence and individual accountability. The positive interdependence is less strengthened and the individual accountability is ruined in most group presentation (Tamah, 2015). In other words, a conventional group work presentation is assumed to decrease the value of positive interdependence and individual accountability from each group member.

Prior to those concerns, this recent study will try to apply different kinds of group presentation model to undergraduate students and find out their perspectives towards this different kind of group presentation model.

Meanwhile, the group presentation model is referred to the model by Tamah and Prijambodo on their book Model Asesmen Pembelajaran Kooperatif: Strategi Menjawab Tantangan (2015), namely $A$-aikem 3 model. After studying different kinds of 
Jurnal Edukasi, Volume 5 No.2, Oktober 2019

EISSN. 2598-4187 ISSN. 2443-0455

group presentation models, Model Aaikem 3 is considered to be an intriguing and challenging model because of several reasons. First, this model facilitates the degree of fairness because it uses a lottery mechanism to determine the role of each group member. Second, this model strengthens the value of positive interdependence and individual accountability among each group member. As mentioned by Slavin (1996) each student in the same group has a unique contribution to make to the joint effort. Team members depend and rely on one another to achieve the goal. Each group member's effort is required and indispensable for group success. Therefore, all students in a group must be accountable for contributing their own share of the work and mastering all of the materials to be learned to the group's success. And the last reason of choosing this model is because of its novelty.

Inspired by those previous studies, this present study focused on the student's perspective towards the use of a relatively new model in group presentation coined by Tamah and Prijambodo (2015) on their book Model
Asesmen Pembelajaran Kooperatif: Strategi Menjawab Tantangan. This present study would also like to investigate the positive and negative feedbacks from the undergraduate students after they have experienced the $A$-aikem 3 in their group presentation practices.

\section{Cooperative Learning}

Cooperative learning is one way to provide students with a well defined framework from which they can learn from one another. Students work towards fulfilling academic and social goals that are clearly stated. It is a team approach where the success of each group is dependent on each member actively contributing to the group activity.

Cohen (1994 in Cohen, 2003) defines the process of cooperative learning as a learning environment where every student participates collaboratively on a clearly assigned task. Meanwhile, Johnson, Johnson, and Holubec (1994 in Johnson, Johnson \& Smith, 2007) state that the pedagogical use of small groups is important in CL so that students work together and consequently improve their group learning. 
Jurnal Edukasi, Volume 5 No.2, Oktober 2019

EISSN. 2598-4187 ISSN. 2443-0455

According to some theorists, there are several reasons why CL is important for teaching and learning processes. Johnson et al. (1998) mention the use of CL approach could promote individual student learning. As a result, students learn how to think critically as they work through the specific steps required to achieving a given task. In addition, CL also encourages greater effort among students as they are striving for the mutual benefit of the group.

Consequently, the students gain from each other's efforts and this creates greater productivity, long-term retention and intrinsic motivation in them. Slavin (1990 in Bryson, 2007) agrees that students can share their strengths and also develop their weaker skills through cooperative work. Eventually, it will help students develop their oral skills simply by interacting with each other.

Therefore, by implementing CL in their classroom, students can promote each other's success by orally explaining how to solve problems, teaching one's knowledge to others and by discussing together the concepts being learned. Finally, it will enhance students' satisfaction with their learning

experience.

\section{Essential Components of Cooperative} Learning

Johnson et al. (1998 as quoted in Nam, 2008) systematically define five basic elements into group learning situations which helps ensure cooperative efforts and enable; positive interdependence, promotive interaction, individual and group accountability, interpersonal skill and group processing.

In positive interdependence, each group member has a unique contribution to make and the success of the group is dependent on each member's efforts. Group members have to be aware that their efforts not only benefit themselves individually but also the whole group. Doing so creates a commitment to the success of group members as well as one's own and is the heart of cooperative learning. If there is no positive interdependence, there is no cooperation.

Students need to do real work together in which they promote each other's success by sharing resources and helping, supporting and encouraging each other's efforts to achieve. Students are 
Jurnal Edukasi, Volume 5 No.2, Oktober 2019

EISSN. 2598-4187 ISSN. 2443-0455

shown how to help each other overcome problems and promote each other's success.

In individual and group accountability, each member of the group has to make a significant contribution to achieving the group's goal. The group has to be clear about its goals and what the members have to do to achieve them. Each member of the group is responsible not only for learning but also for helping other members of the group to learn, thus creating an atmosphere of achievement.

In order to promote student's interpersonal skills, students need to know how to interact with one another and as such, direct instruction in social skills and group communication skills are necessary.

Group processing encourages group members to discuss the progress of their project and how to maintain effective working relationships. How the group is working out and other problems they might be facing can also be addressed. Group members need to recognize that they all share the same fate and what affects one member of a group affects them all. (Johnson et al., 1994)

\section{$A$-aikem 3 Group Work Presentation} Model

$A$-aikem 3 model is abbreviated from (Assesmen- aktif, inovatif, kreatif dan menyenangkan) which can be translated into English as an active, innovative, creative and fun assessment model. Basically, $A$-aikem 3 model is one of many $A$-aikem models formulated and designed by Tamah and Prijambodo on their book. The $A$-aikem 3 model developed based on three new insights that are (1) transition from individual (conventional) assessments to group assessment, (2) transition from individual assessment to peer assessment, and (3) transition from Individual assessment without discussion to a representative assessment with discussion. (Tamah \& Prijambodo, 2015 in Tamah, 2017)

A-aikem 3 model is an innovative group work presentation model which emphasizes on CL approach. This model can be used to strengthen positive interdependence, individual accountability, interpersonal and also group processing skill from students.

The key element of this model is the role mechanism which is assigned by 
the use of on the spot lottery. The assigned roles are spokesperson, prompter, technician, and facilitator. The job descriptions of each role are as follows: The task of the spokesperson is to represent the group in the presentation. The job of a prompter is to give help when a spokesperson forgets a particular part of the presentation, or whispers forgotten words, sentences or ideas. The technician's job is to assist in operating computer or media which used in presentation (group members who assist in the operation of computer media such as powerpoint slides). The facilitator's job is to help at the beginning and end of group presentations, such as greeting the opening and greeting for a group presentation (playing the moderator role that delivers and arranges the presentation). 


\section{Role Rotation Guide}

A. For 4-member Groups

\begin{tabular}{|l|c|c|c|c|}
\hline \multirow{2}{*}{ NAME } & \multicolumn{4}{|c|}{ ALTERNATIVE } \\
\cline { 2 - 5 } & 1 & 2 & 3 & 4 \\
\hline AA & $\begin{array}{c}\text { Role } 1 \\
\text { (Spokesperson) }\end{array}$ & $\begin{array}{c}\text { Role 4 } \\
\text { (Facilitator) }\end{array}$ & $\begin{array}{c}\text { Role 3 } \\
\text { (Technician) }\end{array}$ & $\begin{array}{c}\text { Role 2 } \\
\text { (Prompter) }\end{array}$ \\
\hline BB & $\begin{array}{c}\text { Role 2 } \\
\text { (Prompter) }\end{array}$ & $\begin{array}{c}\text { Role 1 } \\
\text { (Spokesperson) }\end{array}$ & $\begin{array}{c}\text { Role 4 } \\
\text { (Facilitator) }\end{array}$ & $\begin{array}{c}\text { Role 3 } \\
\text { (Technician) }\end{array}$ \\
\hline CC & $\begin{array}{c}\text { Role 3 } \\
\text { (Technician) }\end{array}$ & $\begin{array}{c}\text { Role 2 } \\
\text { (Prompter) }\end{array}$ & $\begin{array}{c}\text { Role 1 } \\
\text { (Spokesperson) }\end{array}$ & $\begin{array}{c}\text { Role 4 } \\
\text { (Facilitator) }\end{array}$ \\
\hline DD & Role 4 & $\begin{array}{c}\text { Role 3 } \\
\text { (Technician) }\end{array}$ & $\begin{array}{c}\text { Role 2 } \\
\text { (Prompter) }\end{array}$ & $\begin{array}{c}\text { Role 1 } \\
\text { (Spokesperson) }\end{array}$ \\
\hline
\end{tabular}

\begin{tabular}{|l|c|c|c|}
\hline \multirow{2}{*}{ NAME } & \multicolumn{3}{|c|}{ ALTERNATIVE } \\
\cline { 2 - 4 } & 1 & 2 & 3 \\
\hline AA & $\begin{array}{c}\text { Role 1 } \\
\text { (Spokesperson) }\end{array}$ & $\begin{array}{c}\text { Role 3 and 4 } \\
\text { (Technician \& Facilitator) }\end{array}$ & $\begin{array}{c}\text { Role 2 } \\
\text { (Prompter) }\end{array}$ \\
\hline BB & $\begin{array}{c}\text { Role 2 } \\
\text { (Prompter) }\end{array}$ & $\begin{array}{c}\text { Role 1 } \\
\text { (Spokesperson) }\end{array}$ & $\begin{array}{c}\text { Role 3 and 4 } \\
\text { (Technician \& Facilitator) }\end{array}$ \\
\hline CC & $\begin{array}{c}\text { Role 3 and 4 } \\
\text { (Technician \& Facilitator) }\end{array}$ & $\begin{array}{c}\text { Role 1 } \\
\text { (Prompter) }\end{array}$ \\
\hline
\end{tabular}

B. For 3-member Groups

Source: Tamah \& Prijambodo (2015)

The Student's Perspective on $A$-aikem

\section{Model of Group Work Presentation}

In order to investigate the student's perspective on the implementation of $A$-aikem 3 model of group work presentation, the writer analyzed the result gather from the closed-ended questionnaire and resulted on several findings. Preference and usefulness, individual accountability perceived, positive interdependence and the perception on the difficulties and complexity of $A$-aikem 3 model were discussed as the findings of this research based on the result from the questionnaire which had been distributed to thirty five undergraduate students of STKIP PGRI Sidoarjo.

Preference and Usefulness 
$77.2 \%$ students were consenting to participate in $A$-aikem 3 model of group work presentation activities. This result showed that students had positive preference on the implementation of $A$ aikem 3 model of group work presentation. The numbers of students who strongly agreed to participate on $A$ aikem 3 model of group work presentation is $34.4 \%$ and $42.8 \%$ students agreed to participate and implement $A$ aikem 3 model of group work presentation on their group work presentation activities.

Meanwhile, 68, 5\% students who participated in the implementation of $A$ aikem 3 model of group work presentation agreed that $A$-aikem 3 model of group work presentation had made the students' learning experience easier. From those $68.5 \%$ students who agreed that $A$-aikem 3 model of group work presentation has made their learning experience more easier indicates that the students have positive perception on the usefulness of $A$-aikem 3 model of group work presentation. Meanwhile, only eight point seven per cent $(8,7 \%)$ of thirty five students who think that $A$-aikem 3 model of group work presentation did not make their learning experience easier.

\section{Individual Accountability Perceived}

$77.1 \%$ students have positive perception on the way that $A$-aikem 3 model of group work presentation can improve their attitude towards their work's contribution inside the group. Among those $77.1 \%$ students who have positive perception, $40 \%$ students agreed that their attitude towards the contribution have improved during the group work presentation processes. On contrary, only $2.8 \%$ students who think that $A$-aikem 3 model of group work presentation did not improve their attitude toward the contribution in group processes.

In addition, another result showed that the students perception on A-aikem 3 model of group work presentation which could enhance good working relationships among students was quite high $(82.8 \%)$. That result indicates that $A$ aikem 3 model of group work presentation has positive result on students' group work relationship during 
their learning process using $A$-aikem 3 model of group work presentation.

\section{Positive Interdependence Perceived}

$77.2 \%$ of the students have positive perception regarding the use of role division in $A$-aikem 3 model of group work presentation which can enhance their participation between the group members. It means that role interdependence, one of the characteristic of positive interdependence, was positively perceived during the implementation of $A$-aikem 3 model of group work presentation. Meanwhile, $20 \%$ of the students expressed their neutral perception toward the use of role division which can improve their participation during the group work presentation and only about $2.8 \%$ of the students who negatively perceived the significance of role interdependence.

Meanwhile, $80 \%$ of the students show positive views on level of fairness regarding the need of lottery in order to determine the role of each group members. It means that the majority of the students have perceived a positive role interdependency which is consider as an essential factor in enforcing a positive interdependence among the group members.

\section{Positive interdependence's} factors, is positively perceived. This could be seen from the amount of percentage from the students who perceived the fact that $A$-aikem 3 model of group work presentation can assist and help under achiever students to do the presentation is $62.8 \%$. Meanwhile, only about $2.8 \%$ of the students who have negative perception on the view that $A$ aikem 3 model of group work presentation can assist and help under achiever students during the implementation of $A$-aikem 3 model of group work presentation.

Perception on the Difficulties and Complexity of A -aikem 3 Model

$A$-aikem 3 model of group work presentation is considered as a complicated method to implement by $34.3 \%$ of the students, while $31.4 \%$ of students considered that $A$-aikem 3 model of group work presentation was not a 
complicated method to implement. In addition, $34.2 \%$ of the students have neutral perspective about the intricacy of $A$-aikem 3 model of group work presentation. This result means that $A$ aikem 3 model of group work presentation is a relatively complicated method to implement for these students.

Meanwhile, $68.5 \%$ of the students realize the positive consequences as part of the implementation of $A$-aikem 3 model of group work presentation. Those $68.5 \%$ of the students realized that the mechanism of $A$-aikem 3 model of group work presentation is forcing them to read and master all of the material which is going to be presented and avoid reading the material partially, as often occurs in traditional group work presentation method. It means that $68.5 \%$ of the students are realizing the complexities and difficulties of $A$-aikem 3 model.

Finally, this research reveals that negative tension is felt by $51.5 \%$ of the students during the implementation of $A$ aikem 3 model of group work presentation which made the students could not concentrate on the preparation of their presentation. However, $25.7 \%$ of the student did not feel the negative tension and they can manage their presentation very well.

\section{Students' Positive and Negative Feedback toward the Implementation of $A$-aikem 3 Model}

The results of positive responses from the students show us that $A$-aikem 3 model of group work presentation is preferred by students because the model made them more responsible in group work and prepare the material that had to be presented. In addition, $A$-aikem 3 model of group work presentation is preferred because $A$-aikem 3 model helped the students to share their ideas about the presentation and the material through group discussion, which is a significant element in cooperative learning.

One of the positive feedback said by student $\mathrm{A}$ on his preference to use $A$ aikem 3 model, student A said “ Students will be much more responsible to master all of the materials and the 
students will not only focus on their parts only. It also helps the students to be able in sharing the ideas through discussion in order to achieve good understanding for every group member", the above feedback is aligned with Johnson and Johnson (2002) statement on positive goal interdependence. Johnson and Johnson (2002) said that students perceive that they can achieve their learning goals if' and only if all the members of their group also attain their goals.

In addition, another positive feedback from student $\mathrm{C}$ also supports the use of $A$-aikem 3 model in group work presentation. Student C said " $A$ aikem 3, because it is make the students more responsible about their works.", this means that $A$-aikem 3 model have been enforcing the concept of positive goal interdependence by making students to be more responsible in order to achieve the same goals in their group presentation.

Students think that $A$-aikem 3 model of group work presentation is useful to enhance students' capability to perform and present better in a group work discussion or presentation. It has been posited by Johnson and others that students are either motivated or they are not based on their involvement in their learning with others (Johnson \& Johnson, 2002). Therefore, the statement from Johnson and Johnson (2002) above is proven by the fact that as students become more engaged in their learning, their motivation increases. To be motivated to learn, students need greater opportunity to interact with each other as well as steady encouragement and support of their learning efforts.

In addition, positive interdependence is also perceived as usefulness by the students, because they need to focus and active to understand the whole material and not relying too much on their friend. This finding supported Sarfo and Elen (2011)'s statement which indicates that individuals in the group cannot succeed unless everybody in the group success. In other words, the group members understand that they need each other's support, explanations, guidance in order to achieve the cooperative success. 
Sarfo and Elen (2011) also highlighted the failure of one member ensures the failure of all individuals in the group, therefore, they tend to agree that each efforts will benefit not only to one individual but all individuals in the group.

However, some answers have shown us an interesting perspective. One of the students thinks that $A$-aikem 3 model of group work presentation is much more suitable only for a morning class where the students are usually not working, meanwhile, for evening class was not quite effective because the learning pattern from the students were different and most of the students were working in the morning till the afternoon. Confusion about the procedure of $A$ aikem 3 model is also expressed by the student. Difficulty in understanding $A$ aikem 3 model as a new model really made the student unable to understand the procedure very well.

\section{Conclusion}

The first research question investigates how the undergraduate students perceived A-aikem 3 model of group work presentation. The findings reveal that students have perceived positive perceptions on preferences and usefulness, individual accountability and positive interdependence after implementing $A$-aikem 3 model of group work presentation.

Furthermore, the undergraduate students also perceived individual accountability during the implementation of $A$-aikem 3 model of group work presentation.

The findings and analysis from the students' perception questionnaire also revealed that most of them had perceived positive interdependence. The perceived positive interdependence can be seen from the results which are showing $80 \%$ of the students show positive views on level of fairness regarding the need of lottery in order to determine the role of each group member and $77.2 \%$ of the students have positive perception regarding the use of role division in $A$-aikem 3 model of group work presentation which can enhance their participation among group members. It means that role interdependence, one of the characteristic of positive interdependence, was positively 
perceived by the undergraduate students during the implementation of $A$-aikem 3 model of group work presentation.

The second research question investigates the student's positive and negative feedback on the implementation of $A$-aikem 3 model of group work presentation. The positive feedback from the undergraduate students indicate that $A$-aikem 3 model of group work presentation is preferred by students because unlike traditional model of group work presentation that tend to have low participation in among group members, the new model made them more responsible in term of group work and prepare the material that needed to be presented. In addition, some students think that $A$-aikem 3 model of group work presentation is useful to enhance students' capability to perform and present better in a group work discussion or presentation.

Meanwhile dealing with the positive feedback regarding the use of 'on the spot' lottery to determine the role of each group member, the students think that the use of lottery is effective and fair. Thus, the use of lottery is helping the students to comprehend the whole contents of the materials that they have to present and make the students who rarely active during the presentation become active as they are chosen as the spokeperson.

However, some students also encountered difficulties during the implementation of $A$-aikem 3 model of group work presentation. The necessity to memorize all of the materials that had to be presented is considered as an intricate task for students to deal with.

Despite some difficulties that the students perceived during the implementation of $A$-aikem 3 model of group work presentation, most of the feedback tends to be positive in supporting the use of $A$-aikem 3 model of group work presentation as new model in group presentation.

\section{Suggestions For Further Research}

Future research can build on these findings to refine the instructional resources of $A$-aikem 3 model of group work presentation and offer specific perspective on positive interdependence 
and individual accountability strategies to enhance students' effectiveness and extend the educational settings and academic areas to which they may be applied.

This study did not investigate the quantitative relationships between individual student characteristics and their achievement, interaction, and attitude during the implementation of $A$ aikem 3 model of group work presentation. Such individual differences in student characteristics may have had confounding effects strong enough to make the inference of treatment effects difficult to determine. Further research may provide insight on the role of such individual differences on these relationships and provide a means of modifying the activities to accommodate the profiles and backgrounds of specific students.

Finally, this study did not investigate the effectiveness of positive interdependence-plus-individual accountability on student achievement, interaction, and attitude after they experience $A$-aikem 3 model of group work presentation. Previous research on positive interdependence has shown that combined interdependence strategies such as roles-plus-rewards are often a more effective influence on student interaction than any single strategy.

Therefore, future studies can provide additional insights of experimental research on effective use of $A$-aikem 3 model of group work presentation by exploring how students interact with each other when they receive combined interdependence-plusindividual accountability treatment in their group activities.

\section{References}

Brown, H. D. (2001). Teaching By Principles: An Interactive Approach To Language Pedagogy. Englewood Cliffs, NJ: Prentice Hall Regents (2nd ed.). White Plains, NY: Longman.

Cohen, J. (2003). Applied Multiple Regression/Correlation Analysis for The Behavioral Sciences (3rd ed.). Mahwah, NJ: Lawrence Erlbaum Associates.

Johnson, D. W., \& Johnson, F. (2006). Joining together: Group theory and group skills (9th ed.). Boston, MA: Allyn \& Bacon.

Johnson, D.W., \& Johnson R.T. (1994). Learning together. In S. Sharan (Ed.), Handbook of cooperative 
Jurnal Edukasi, Volume 5 No.2, Oktober 2019

EISSN. 2598-4187 ISSN. 2443-0455

learning methods (pp. 51-81). Westport, CT: Greenwood Press.

Johnson, D.W., Johnson, R.T., \& Smith, K.A. (1998). Cooperative learning returns to college. Change, 30(4), 26-35.

Johnson, D. W., Johnson, R. T., \& Smith, K. (2007). The state of cooperative learning in Post secondary and professional settings. Educational Psychology Review, 19(1), 33-38

Johnson, D.W., Johnson, R.T., Stanne, M.B., \& Garibaldi, A. (1989). Impact of group processing on achievement in cooperative groups. Journal of Social Psychology, 130, 507-516.

Sarfo, F \& Elen, J. (2011) Investigating the Impact of Positive Resource Interdependence and Individual Accountability on Students' Academic Performance in Cooperative Learning. Electronic Journal of Research in Educational Psychology. 9(1), 7394.

Slavin, R. (1995). Cooperative learning: Theory, research and practice (2nd ed.). Needham Heights, MA: Allyn \& Bacon.

Slavin, R. (1988). Educational psychology: Theory into practice (2nd ed.). Englewood Cliffs, NJ: Prentice-Hall.

Strahm, M. F. (2007). Cooperative Learning: Group Processing and
Students Needs for Self-Worth and Belonging. The Alberta Journal of Educational Research 53(1), 63-76.

Tamah, S. M. (2011). Student Interaction in the Implementation of the Jigsaw Technique in Language Teaching. Published thesis, the University of Groningen, Groningen, the Netherlands.

Tamah, S. M. (2012). Teacher's Enforcing Positive

Interdependence:Students'

Perceptions. Magister Scientiae 31(7), 74-83.

Tamah, S. M. (2014). Idea Sharing: Assessment in a Cooperative Learning Class. PASAA 47, 200-210.

Tamah, S. M. (2015). Innovation in Group Work Presentation: A Challenge Responded. Proceedings of The 24th MELTA International Conference (pp. 380-393). Kuala Lumpur: August Publishing Sdn. Bhd.

Tamah, S. M. (2017). Pernak-Pernik Kerrja Kelompok Berbasis Pembelajaran Kooperatif. Surabaya: Universitas Katolik Widya Mandala Surabaya.

Tamah, S. M., \& Prijambodo, V. L. (2015). Model Asesmen Pembelajaran Kooperatif: Strategi Menjawab Tantangan. Surabaya: Revka Petra Media. 